\title{
Institutional Treatment for Juveniles in India- A Critical Analysis
}

\author{
Dr. Nandini. G. Devarmani
}

Assistant Professor, School of Criminology and Criminal Justice, Rani Channamma University, Belagavi, Karnataka, India

\begin{abstract}
India is a home to almost $19 \%$ of the World's children. More than one third of the country's population is below 18 years. The children are considered as the future productive citizens of the country, therefore it is necessary to make them healthier, educated, protected and well developed child. $40 \%$ of India's children are vulnerable to or have difficulties in living a normal standard life. Juvenile Delinquency is a subject which attracted the attention of the law makers in India for over the last 150 years. The subject is a sign of sick society. Overcrowding in cities increasing number of slums, gambling drinking etc are some of the factors responsible for delinquency rate. Indian society in general though rural in character, cannot escape the impact of urbanization resulting in crime and delinquency. The internal and external environment or the psychopathological elements in the individual play an important role in shaping the child's future. The future of Juveniles is not dark, but needs proper long term perspective and planning.

The' right to life and personal liberty is the most precious right guaranteed under our Indian Constitution. This right is curtailed when a person is sent to institutions but it is necessary to such action from reformation point of view. As Gandhiji said a 'person cannot be corrected by hate but by love and affection' especially when it comes to CHILDREN. This paper discusses the children who are in need of care and protection, who if not dealt with will definitely lead to a great social problem in the near future. In spite of several dilemmas of correctional administration this paper tries to reflect the various treatment methods (Institutional and non-institutional) for the juveniles in India. The Correctional Institutions are to be looked upon as hospitals and the children in need of care and protection as the patients, what is needed is just a treatment to make him/her fit for the society.
\end{abstract}

Keywords - Institution, Juvenile, CICWL,CINOCAP, CWC, JJB, Children's home, Special Home, Foster care, After care hostels.

\section{INTRODUCTION}

"I am the Child, all world waits for my coming, all earth watches with interest to see what I shall become, Civilization hangs in the balance, For what I am, the world of tomorrow will be. I am the child, you hold in your hand my destiny, You determine, largely, whether I shall succeed or fail, Give me, I pray you, these things that make for happiness, Train me, I beg you, that I may be a blessing to the world"

\section{Maime Gene Gole}

Each and every child in society irrespective of cast, creed, color, sex, region and status wishes as stated above, but as we know that every child is not born with a silver spoon in its mouth. There are children who don't have parents or anyone to take care of them, there are some who have parents but are unable to take care of them. In the absence of parent or guardian it is the responsibility of the state to take care of such children. Apart from this the State is also responsible to take care of the Juveniles who are in conflict with the law as there are two sections under IPC which are part of general exceptions .

Juveniles in India are categorized in two groups, one which comprise of CINOCAP (Child In Need Of Care and Protection) and the other CICWL. (Children In Conflict With Law)In both cases children means a person who is below the age of 18 years. The Juvenile Justice policy in India is structured around the constitutional mandate prescribed as per Articles 15(3),39(e) and (f), 45 and 47 and also the UN Convention on the rights of the Child (CRC) and UN Standard Minimum Rules for Administration of Juvenile Justice (Beijing Rules). The problematic children can be classified as vagabonds, orphans, destitute, beggars, truants, mischievous children and children who are in conflict with law (girl /boy below the age 18 years and who has committed an offence).This is the category which needs to be attended so that the future of the country is in safe hands, as it is said that the future of one's country is in the hands of its youth. Corrections may be institutional or noninstitutional. 
The goals of corrections include: Reformation, Humanization, recognize the rights, Reorient institutions, introducing scientific methods etc. The juveniles can be classified as:

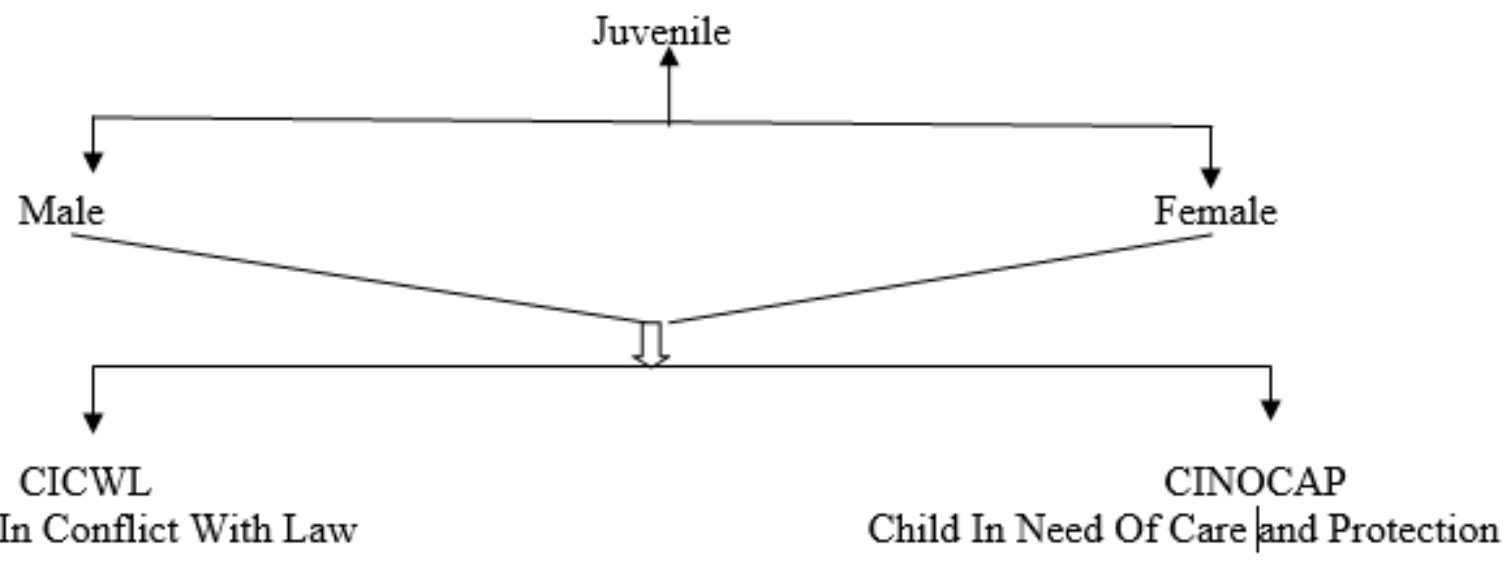

Institution is a government or a registered non governmental organization or a voluntary organization prepared to own the responsibility of a child(person who has not completed the age of eighteen years) and such organization is found fit by the competent authority. These institutions are set at every district (in some places it is for group of districts) separately for girls and boys. Each and every institution should have a separate residence facilities for different age groups with minimum requirements of dormitory, workshop, Classrooms, dining hall, recreation room, library, Playground equipped with adequate lighting, ventilation, sufficient treated drinking water, clean bathrooms and toilets, heating and cooling arrangements, fire extinguishers, first-aid kits etc.

Every institution has a management committee which manages or monitors the progress of the institution (every juvenile).The committee consists of the DCPO (District Child Protection Officer) who is the Chairperson, Officerin-charge who is the member Secretary, and Probation Officer/Child Welfare Officer/Case worker who is a member of the committee. The other members of the committee are - medical officer, Counselor / Psychologist, Workshop supervisor, teacher, Social worker who is a member of the CWC or JJB, Juvenile representative and voluntary organizations providing services are special invitees.

There are two separate committees to handle the problematic children.

$>$ CWC-Child Welfare Committee-comprises of five members, one is the chairperson and others are the members (atleast one member should be women)

$>$ JJB-Juvenile Justice Board-comprises of three members, a metropolitan Magistrate who has special knowledge of the child welfare /social welfare and two social workers out of which one should be a women representative.

Once the children are instutionalised by the above committees they are kept in either of the institutions like Children's Home, Observation Home, Special Home, AfterCare Hostel, Fit Institution or they can be given for adoption /foster care.

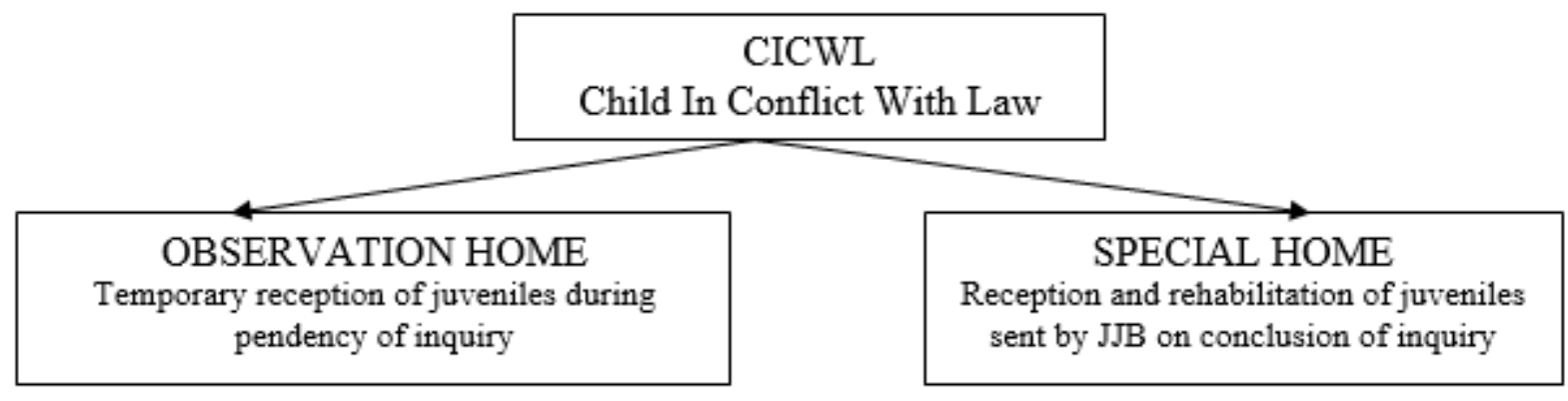




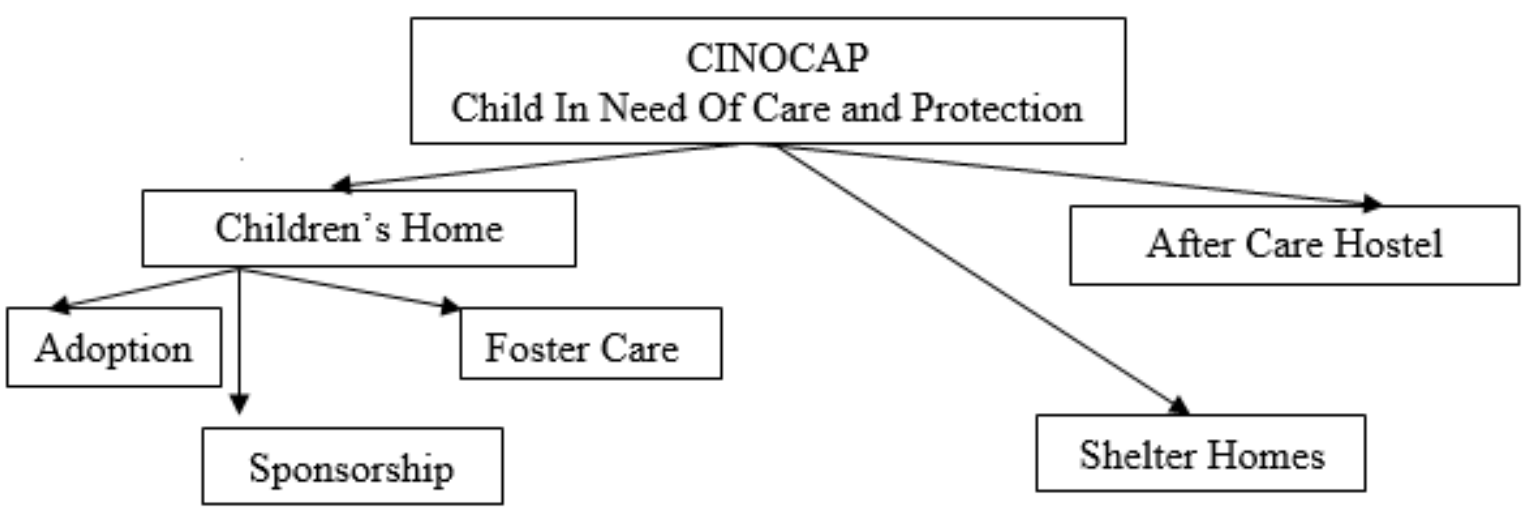

Statistics of Juveniles: There are a total of 815 Juvenile homes in India. They are overcrowded as the number of juveniles accused and need counseling is 1.7 million. The crimes committed by juveniles are on an increasing trend as reported by the National crime record bureau. The number of crimes committed by juveniles in the year 2001 was 16509 which has raised to 25125 in the year 2011 , that is to say that there is a rise of $65.7 \%$ in a decade.

Going to the state wise statistics on juveniles in the year 2011 it is found that Madhya Pradesh has higest number of juvenile crimes of 4997 followed by Maharastra - 4775 .

Role of the Police in Juvenile Justice: The police as an organization play its role in three different levels. At the state level the Inspector General of police is the Nodal Officer, then at the District /City level There is SJPU (Special Juvenile Police Unit) headed by the SP and at the police station level there are Juvenile or Child welfare Officers (JCWO).When the police apprehend the Juvenile,the case may be disposed if it is petty offence ,juvenile may be apprehended in non-serious offences in the interest of the child and in case of serious offences the juvenile is apprehended. On apprehension the juvenile is not to be handcuffed or sent to jail instead the juvenile is to be handed over to nearest JCWO. Later information is to be given to the parents and probation officer to obtain Social Investigation Report. The parents must be informed in detail regarding the date, time and place, need of surety and bail bond give a copy of the police report and ask to produce the proof of juvenility. Before the juvenile is handed to the JCWO it is the responsibility of the police to look after the food, safety and other amenities and to see that the juvenile is produced before the Board within 24 hours.

Children's Home: established by the State government or in association with the voluntary organizations, in every district (or group of districts) for the reception, care, treatment, education, training, development and rehabilitation of the child in need of care and protection.

They are registered as child care institutions and certified. Children of both sexes below the age of ten years can be kept in a single home but facilities may differ from age to age i.e facilities for infants differ from those above the age of five years .For children above the age of ten years separate institutions must be set up for boys and girls. The main objective of the children's home is to promote an integrated approach to child care by involving the community and NGO's.

Shelter Homes: The State government assist the voluntary organizations to set up and administer homes where a child is brought and kept in emergency by any police officer/SJPU /any public servant/childline/voluntary organization/social worker/public/child himself. Shelter Homes include short stay homes (temporary stay for a maximum period of one year) ,Transitional Homes ( immediate care for a maximum period of four months), 24 hours drop in centres ( for day care or night shelter) There shall be separate shelter homes for girls and boys with minimum lodging and boarding facilities.

Adoption: when the child is in the children's home the committee shall give the child in adoption to a family who is willing and capable to take full responsibility of the child.(provided all the conditions of JJ Act and the Adoption Act are fulfilled). The primary aim of adoption is to provide permanent substitute family to a child whose biological parents are not able to take care.

Foster care: Children from children's home may be placed or given the responsibility of care and protection to other families for a short or temporary period. During this the Childs own parents can go and meet the child and also the child may return to his own family. Foster care can be provided only to those children who cannot be given in adoption. The foster parents must be emotionally stable, financially sound, medically fit and must be able to take care of the child. There shall be no discrimination of caste, 
religion, ethnic status etc but decision will be taken in the best interest of the child.

Sponsorship: It's a supplementary support provided to children's home, special home or to the families to meet the medical, educational, nutritional and other needs of children. It may be individual, group or community sponsorship.

After-care hostels: Set up by the State government for juveniles above 18 years of age and those who leave the children's home and special home. The maximum period of stay is three years i.e. upto the age of 21 years. The programme encourages to provide vocational training to gain employment and gradually sustain themselves without any support. Stipend will be provided during the training period and also loans may be arranged to set up entrepreneurial activities.

Children in these institutions must be provided with the following facilities:

Accommodation along with bedding and clothing (4-6 sets per year).Sanitation and hygiene - Water facility for drinking and cleaning, Proper drainage system, sufficient toilets and bathrooms. Diet -4 meals a day(special diet for sick, special meals on holidays and festivals)Medical monthly medical check-up, drug abuse preventive programmes etc. Education - Arrangements for inside and outside the institution, extra coaching classes. Daily routine including physical exercise, recreation, vocational training etc.

The fundamental principles of Juvenile Justice System are:

$>$ Principle of presumption of innocence.

$>$ Principle of dignity and worth.

$>$ Principle of right to be heard.

$>$ Principle of best interest.

$>$ Principle of family responsibility.

$>$ Principle of safety.

$>$ Positive measures.

$>$ Principle of non-waiver of rights.

$>$ Principle of equality and non-discrimination.

$>$ Principle of right to privacy and confidentiality.

$>$ Principle of last resort.

$>$ Principle of fresh start.

$>$ Principle of repatriation and restoration.

$>$ Principle of non-stigmatizing semantics, decisions and actions.

Probation officer plays a vital role in Juvenile Justice System. He must be a friend, philosopher and a guide to the juveniles. Once the juveniles are handed over by the SJPU they are under the probation officers. The PO is appointed by the State government .Honorary PO is appointed by the voluntary organizations. As already stated the future of the www.ijels.com juvenile is the hands of the probationary officers. After the juvenile is apprehended the PO has to collect information of antecedents and family background, School and work record, neighborhood information of the juvenile, prepare the investigation report, take a photograph of the juvenile, supervise the juvenile in case of bail/at the time of final order/post release, assistant the institution. When a juvenile is placed under a PO he is the case worker, PO has to prepare the care plan and follow up of the juvenile. They should also assist the juvenile to develop contact with the family , assist the family members, visit place of residence school/occupation, help in social reintegration (by establishing linkages with voluntary organizations) and follow up the juvenile even after release.

On reception of the juvenile a thorough search is made, given bath and hair cut (if necessary) all his belongings are disinfected and kept safely. Juvenile is issued with necessary items like clothes, bedding, soaps etc. Medical examination is made and if necessary treatment is given in case the juvenile is suffering from any contagious or infectious disease .later the juvenile is placed in the prescribed place of residence and his daily activities of education and other necessary routine work are taken care of. The juveniles are provided with facilities of communication (to talk with their parents/relatives), visit by the parents /guardians and also leave facility where the juvenile is escorted either by the parents or the PO. If the juvenile escapes during leave than the case must be reported to the nearest police station.

\section{CONCLUSION}

Rehabilitation and social reintegration of the child is the primary object which is discussed in the earlier part of the paper i.e. adoption, foster care, sponsorship sending the child to an after-care organization. The purpose is to restore dignity and self-confidence among the children and bring them back to a normal family life. Every child in the country has a legitimate claim and is entitled to its share in the finances of the Republic for harmonious and comprehensive development of its personality. As a plant needs protection, nourishment and proper environment to grow into a big fruit - bearing tree, a child also needs protection, promotion, nourishment and proper environment to grow into a useful and responsible citizen. Proper Health, Education and Environment for the children are the imperative needs of the hour.

Children are the supreme asset of any nation; they are the greatest gift to Humanity. Children are the potential and useful human resources for the progress of the country .Children are innocent, vulnerable and dependent. The

Page | 13 
Constitution of India articulates the concern for the children as per the Articles 15, 24, 39(e), 39(f) 47, and 51A with special reference to Article 39 (e) which indicates The State is the guardian of the Health and Strength of the children. Therefore, they are to be provided with all necessary facilities and atmosphere to grow into responsible and useful citizens of the country. For full and harmonious development the child should grow up in a family environment, in an atmosphere of happiness, love and understanding. Apart from globalization, liberalization, modernization and privatization there should be another important element - Humanization, so that the Human Rights violations including the violations of the Rights of the Children. Children being the supreme asses of the country, they are to be looked after and groomed well.

\section{GOLDEN WORDS by Gabriel Mistral (Nobel Prize winner from Chile)}

"We are guilty of many errors and faults; But our worst crime is abandoning the children, Neglecting the foundation of life, many of the things we need can wait, The child cannot wait; Right now is the time, His bones are being formed, His blood is being made and his senses are being developed, To him, we cannot answer 'tomorrow'; His name is 'today'.,'

\section{REFERENCES}

[1] Ahuja, Ram (2005). Criminology, Rawat Publications: New Delhi.

[2] Ahuja, Ram (2007). Social Problems in India, Rawat Publications: New Delhi.

[3] Crime in India 2010. NCRB, New Delhi: Government of India.

[4] Crime in India 2011. NCRB, New Delhi: Government of India.

[5] Chaudhry, Lakshmi (2012) 'Guwahati Incident: Pathology of 'New' and 'Free' India' First post July 13.

[6] Bhambri, Vaishali (2012) 'Lady Cops for Rape Cases, Girls Approve' Hindustan Times New Delhi, June 03.

[7] Mangoli R.N (2010). Sexual Harassment of Women at Workplace, Indian Journal of Human Rights and Social Jusitce 5:157-167.

[8] Singh, Dalip (2012). 'Shame on men, for crimes against women' Deccan Herald, July 21.

[9] Azim, Shaukath (1997). Muslim Women: Emerging Identity, Rawat Publications: New Delhi.

[10] Azim, Shaukath (2009). 'Impact of Environmental Degradation on Women', Environmental Concerns and Sustainable Development: Some Perspectives from India, Edited by Ganesha Somayaji, Teri Press: New Delhi.

[11] Pandey, Sanjay (2012) 'UP Cops gang-rape woman in police station’ Lucknow, Deccan Herald, July 23.

\section{Reports}

1. Report of National Expert Committee on Women Prisoners, 1986-87.

2. Report of the All India Jail Reforms Committee, 1980-83.

3. Report of the Indian Jails Committee, 1919.

4. Report of the Departmental Jail Committee, 1939.

5. Report of the U.P. Jail Reforms Committee, 1946.

6. Report of the Women's Jail Committee, 1946.

7. Report of the All India Jail Manual Committee, 1955.

8. Report of the Jail Reforms Committee, Maharashtra, 1948. 9. Report of the Jail

9. Report of the Committee on the "Status of Women in India", Government of India

10. Report on the "Women in India", Government of India, Ministry of Social

11. Crime in India Report, 2000-2009- Bureau of Police research and Development, New Delhi. 